ISSN : 1979 - 7362

\title{
PendugaanLengas Tanah Inceptisol Pada Tanaman Hortikultura Menggunakan Citra Landsat 8
}

\author{
Nurilmi $^{1}$ Mahmud Achmad ${ }^{1}$ dan Suhardi ${ }^{1}$ \\ Program Studi Teknik Pertanian, Universitas Hasanuddin Makassar
}

\begin{abstract}
ABSTRAK
Ketersediaan air tanah atau kadar lengas tanah merupakan salah satu faktor penting bagi tanaman secara umum. Salah satu cara mengetahui lengas tanah yaitu dengan bantuan citra satelit. Inceptisol merupakan tanah muda dan mulai berkembang. Bertekstur gembur, warna tanah gelap, mempunyai struktur yang baik, dan cukup subur. Tujuan dari penelitian ini adalah untuk membangun algoritma pendugaan kelengasan tanah dari komponen citra Landsat 8 Di Kelurahan Bajeng, Kecamatan Patalassang, Kabupaten Takalar. Metode yang dilakukan pada penelitian ini meliputi pemotongan citra, koreksi radiometrik, pengembangan model pendugaan kadar lengas tanah menggunakan citra Landsat 8, dan pembuatan peta kontur lengas tanah. Berdasarkan hasil penelitian menunjukkan algoritma pendugaan pada band 2 biru menghasilkan koefisien determinasi $\left(\mathrm{R}^{2}\right)$ sebesar 0,653 dengan persamaan $\mathrm{LT}$ = 130.2(B2) $)^{2}+114.0(\mathrm{~B} 2)+11.08$. Pada Soil Adjusted Vegetation Index (SAVI) menghasilkan koefisien determinasi $\left(\mathrm{R}^{2}\right)$ sebesar 0,843 dengan persamaan $\mathrm{LT}=324,6(1,5 \mathrm{x}((\mathrm{B} 5-\mathrm{B} 4)$ $/(\mathrm{B} 5+\mathrm{B} 4+0,5))^{3}-387,7\left(1,5 \times((\mathrm{B} 5-\mathrm{B} 4) /(\mathrm{B} 5+\mathrm{B} 4+0,5))^{2}+135,5(1,5 \times \quad((\mathrm{B} 5-\mathrm{B} 4) /\right.$ $(\mathrm{B} 5+\mathrm{B} 4+0,5))+20,78$. Pada kromatisasi hijau menghasilkan koefisien determinasi $\left(\mathrm{R}^{2}\right)$ sebesar 0,576 dengan persamaan $\mathrm{LT}=2 \mathrm{E}+10(\mathrm{~B} 3 / \mathrm{B} 2+\mathrm{B} 3+\mathrm{B} 4)^{3}-2 \mathrm{E}+10\left((\mathrm{~B} 3 / \mathrm{B} 2+\mathrm{B} 3+\mathrm{B} 4)^{2}\right.$ $+8 \mathrm{E}+09(\mathrm{~B} 3 / \mathrm{B} 2+\mathrm{B} 3+\mathrm{B} 4)-8 \mathrm{E}+08$.
\end{abstract}

Kata kunci: Lengas Tanah Inceptisol, Citra Landsat 8, Kelurahan Bajeng, Algoritma Pendugaan

\section{PENDAHULUAN}

\section{Latar Belakang}

Indonesia merupakan salah satu negara agraris, dimana terdapat berbagai macam tanaman yang dapat tumbuh dan berkembang. Ketersediaan air tanah atau lengas tanah merupakan salah satu faktor penting bagi tanaman agar dapat tumbuh dengan baik, terlebih untuk lahan pertanian secara umum. Hampir setiap proses yang terjadi di dalam tubuh tanaman langsung atau tidak, sangat dipengaruhi oleh ketersediaan air. Lengas tanah merupakan air yang terkandung di dalam pori-pori tanah. Inceptisol merupakan salah satu jenis tanah muda yang belum berkembang lanjut sehingga kebanyakan tanah ini cukup subur, kandungan bahan organik tinggi, gembur, warna tanah gelap, dan mempunyai struktur yang baik. Tanah inceptisol banyak dijumpai di wilayah penanaman padi sawah.
Terdapat beberapa cara untuk mengetahui tingkat lengas tanah diantaranya adalah dengan teknik gravimetrik, tensiometer dan neutron probe. Teknik-teknik tersebut dapat memberikan informasi yang akurat, akan tetapi memerlukan biaya besar untuk pengukuran wilayah yang sangat luas. Cara lain yang dapat dilakukan yaitu dengan bantuan data satelit dan Sistem Informasi Geografis (SIG).

Sistem Informasi Geografis (SIG) merupakan suatu sistem informasi yang tidak terlepas dari data spasial, yang merupakan sebuah data yang mengacu pada posisi, objek dan hubungan diantaranya dalam ruang bumi. Data spasial merupakan salah satu item dari informasi di mana di dalamnya terdapat informasi mengenai bumi termasuk permukaan bumi, di bawah permukaan bumi, perairan, kelautan dan bawah atmosfer. 
Penginderaan jauh merupakan suatu ilmu yang digunakan untuk memperoleh informasi alat tanpa kontak langsung terhadap objek. Data penginderaan jauh dapat diperoleh melalui hasil rekamansatelit,salah satunya dengan citra satelit Landsat 8 . Landsat 8 sangat membantu dalam menyajikan informasi berdasarkan reflektansi panjang gelombang. Pengunaan citra satelit diharapkan dapat mempermudah dalam pengumpulan data yang mencakup wilayah yang luas dan dapat mengurangi biaya yang akan dikeluarkan.

Informasi mengenai lengas tanah (soil moisture) sangat dibutuhkan untuk perencanaan, pengelolaan dan pemantauan budidaya tanaman pertanian. Maka dari itu dibutuhkan penelitian untuk Pendugaan Tingkat Kelengasan Tanah Pada Tanaman Hortikultura Di Kelurahan Bajeng, Kecamatan Patalassang, Kabupaten Takalar Menggunakan Citra Landsat 8.

\section{Tujuan dan Kegunaan}

Tujuan dari dilakukannya penelitian ini adalah untuk membangun algoritma pendugaan lengas tanah inceptisol dari komponen citra Landsat 8.

Kegunaan penelitian ini yaitu untuk memberikan informasi tentang algoritma fungsi kelengasan tanah untuk citra Landsat 8 dan pemetaan lengas tanah dengan Landsat 8.

\section{TINJAUAN PUSTAKA}

\section{Kelengasan Tanah}

Kadar lengas tanah sering disebut sebagai kandungan air (moisture) yang terdapat dalam pori tanah. Satuan untuk menyatakan kadar lengas tanah dapat berupa persen berat atau persen volume. Beberapa faktor yang memengaruhi kandungan lengas dalam tanah antara lain iklim, cara pemberian air irigasi, kandungan bahan organik, fraksi lempung tanah, topografi, dan adanyabahan penutup tanah baik organik maupun anorganik (Ritawati et al, 2015).
Kelembaban tanah dapat didefinisikan sebagai air yang tak jenuh dari suatu profil tanah, yaitu antara permukaan tanah dan air tanah. Air tanah sangat penting untuk studi perubahan iklim, dan untuk melakukan pengukuran keseimbangan air tanah. Informasi mengenai air tanah diperlukan untuk parameterizing model numerik, yang digunakan untuk memperkirakan jumlah penguapan yang terjadi pada suatu tutupan lahan, dan perkolasi untuk studi dampak air tanah. Variabel spasial dan temporal kelembaban air tanah di dapatkan dari hasil variasi tekstur tanah, topografi, cover crop, praktek irigasi dan kedalaman muka air tanah. Estimasi kelembaban air tanah penting untuk pengelolaan sumber daya air, untuk aplikasi meteorologi dan terutama bagi pertanian. Informasi kelembaban tanah jangka panjang juga sangat penting untuk pemantauan kekeringan pertanian dan prediksi hasil panen (Malik dan Shukla, 2014).

Terdapat beberapa metode pengukuran langsung yang dapat digunakan dan akurat untuk menentukan lengas tanah atau kadar air tanah. Observasi lapangan atau pengambilan data lapangan juga memberikan dasar untuk memahami hasil dari teknik penginderaan jauh. Metode dasar pengukuran langsung di lapangan yang paling umum digunakan untuk estimasi kelembaban tanah diantaranya adalah metode gravimetrik, neutron probe dan metode berdasarkan sifat tanah dielektrik. Metode gravimetri memperkirakan kadar air dalam tanah dengan menimbang sampel sebelum dan setelah pengeringan dalam oven. Metode neutron probe menggunakan kemampuan hidrogen untuk memperlambat neutron yang cepat dan juga lebih efisien daripada zat lainnya. Metode dielektrik didasarkan pada perbedaan besar antara konstanta dielektrik air dan dari tanah terkering(Malik dan Shukla, 2014).

Anonim (2011), melakukan penelitian mengenai analisis kelembaban tanah permukaan melalui citra Landsat 7 
ETM+ di wilayah dataran Kabupaten Purworejo. Penelitian tersebut bertujuan untuk mengetahui hubungan nilai spektral dengan kelembaban tanah permukaan, mengetahui hubungan kelembaban tanah permukaan terhadap liputan vegetasi dan temperatur permukaan, serta menganalisis hubungan antara kelembaban tanah permukaan dengan penggunaan lahan di wilayah dataran Kabupaten Purworejo.

Domiri (2005), melakukan penelitian mengenai pengembangan model pendugaan kelengasan lahan menggunakan data MODIS. Penelitian bertujuan untuk membuat model pendugaan untuk memantau kondisi kelengasan lahan pertanian, terutama padi sawah menggunakan data MODIS yang memiliki resolusi spasial $250 \mathrm{~m}$ dan $500 \mathrm{~m}$ serta pengamatan harian.Suatu indeks yang disebut Indeks Kelengasan Lahan (IKL) telah dibuat berdasarkan hasil transformasi komponen utama pertama dari NDSI, NDVI dan NDWI. Pada penelitian tersebut, menunjukkan bahwa semua indeks memiliki respon positif terhadap kenaikan lengas lahan, tetapi NDVI lebih sensitif dengan korelasi yang lebih kuat. NDVI yang meningkat terkait dengan penutupan vegetasi yang meningkat pula. Kondisi tersebut menunjukkan bahwa lahan yang bervegetasi rapat relatif kondisinya lebih lembab dari lahan yang bervegetasi jarang.

\section{Tanah Inceptisol}

Incetisol merupakan tanah muda dan mulai berkembang. Profilnya mempunyai horison yang dianggap pembentukannya agak lamban sebagai alterasi bahan induk. Tanah inceptisol mudah berubah oleh gerakan fisik atau reaksi kimia, mempunyai kadar liat $>60 \%$, remah sampai gumpal, gembur, warna tanah gelap, solum dalam $(>150 \mathrm{~cm})$, kejenuhan basa rendah $(<50 \%)$, dan mempunyai struktur yang baik. Tanah inceptisol banyak dijumpai di wilayah penanaman padi sawah, selain itu tanah ini gembur dan cukup subur. Inceptisol dapat berkembang dari bahan induk batuan beku, sedimen dan metamorf. Karena Inceptisol merupakan tanah yang baru berkembang biasanya mempunyai tekstur yang beragam dari kasar hingga halus, dalam hal ini dapt bergantung pada tingkat pelapukan bahan induknya (Nurdin, 2012).

\section{Sistem Informasi Geografis (SIG)}

Sistem Informasi Geografis adalah sistem informasi khusus yang mengelola data yang memiliki informasi spasial (bereferensi keruangan). Atau dalam arti yang lebih sempit, adalah sistem komputer yang memiliki kemampuan untuk membangun, menyimpan, mengelola dan menampilkan informasi berefrensi geografis, misalnya data yang diidentifikasi menurut lokasinya, dalam sebuah database(Purwadhi dalam Bahar, 2016).

Menurut Anonim (2014), data spasial terbagi atas dua model data yaitu model data raster dan model data vektor. Keduanya memiliki karakteristik yang berbeda, yaitu :

1. Vektor

Model ini berbasiskan pada titik (points) dengan nilai koordinat $(\mathrm{x}, \mathrm{y})$ untuk membangun objek spasialnya, objek yang dibangun terbagi menjadi tiga bagian lagi yaitu berupa titik (point), garis (line), dan area (polygon).

2. Data raster

Data raster (disebut juga denga sel grid) adalah data yang dihasilkan dari sistem penginderaan jauh. Pada data raster, obyek geografis direpresentasikan sebagai struktur sel grid yang disebut dengan pixel (picture element).

\section{Penginderaan Jauh}

Penginderaan jauh merupakan suatu ilmu yang digunakan untuk memperoleh informasi tentang obyek, daerah, atau gejala dengan cara analisis data yang diperoleh dengan menggunakan alat tanpa kontak langsung terhadap obyek, daerah, atau gejala tersebut. Data penginderaan jauh dapat diperoleh melalui hasil rekaman 
sensor yang dipasang baik pada pesawat terbang,satelit, pesawat ulang alik, atau wahana lainnya. Sensor tersebut akan menghasilkan data yang berbeda-beda sesuai dengan letak ketinggian sensor maupun karakteristik obyek yang dikaji (Andana, 2015).

Pixel adalah sebuah titik yang merupakan elemen paling kecil pada citra satelit. Angka numerik (1 byte) dari pixel disebut nilai digital (DN). DN bisa ditampilkan dalam warna kelabu, berkisar antara putih dan hitam (gray scale), tergantung level energi yang terdeteksi. Pixel yang disusun dalam orde yang benar akan membentuk sebuah citra. Kebanyakan citra satelit yang belum diproses disimpan dalam bentuk gray scale. Untuk penginderaan jauh, skala yang dipakai adalah 256 shadegray scale, dimana nilai 0 menggambarkan hitam, nilai 255 putih (Cifor dalam Sinadia, 2015).

\section{Reflektansi}

Reflektansi adalah suatu bahan pada cahaya yang menyebar/dipantulkan jika cahaya tersebut jatuh pada permukaan objek. Nilai reflektansi dapat diukur dengan menghitung rasio cahaya yang dipantulkan terhadap jumlah cahaya yang datang. Reflektansi dapat disimbolkan dengan $\rho$, sedangkan distribusi reflektansi pada suatu citra dapat disimbolkan dengan r (x,y) (Puntodewo, 2010).

Untuk mengetahui tingkat lengas tanah, analisis mengenai data pantulan permukaan tanah di daerah terlihat dan infra merah dekat dalam hubungannya dengan data kelembaban permukaan pada lingkungan untuk menentukan hubungan antara keduanya dan untuk mengidentifikasi metode potensial untuk estimasi kelembaban tanah dari data penginderaan jauh pada panjang gelombang yang berbeda dapat dilakukan (Malik dan Shukla, 2014).

Rentang spektral yang biasa digunakan dalam penginderaan jauh berkisar antara panjang gelombang $0,4 \mu \mathrm{m}$ dan $12 \mu \mathrm{m}$ (mencakup sinar tampak dan infra merah), dan antara $3 \times 10^{3} \mathrm{~mm}$ sampai dengan $3 \times 10^{5} \mathrm{~mm}$ yang sering disebut juga sebagai gelombang mikro. Pada daerah sinar tampak dan infra merah dekat maupun infra merah sedang, energi yang direfleksikan dan direkam oleh sensor sangat tergantung pada sifat-sifat objek yang bersangkutan misalnya kadar air, pigmentasi daun, maupun struktur daun. Pada daerah infra merah termal, kekuatan radiasi yang dapat dideteksi sensor dipengaruhi oleh kapasitas panas dan sifatsifat termal dari permukaan maupun dibawah permukaan tanah (Prahasta, 2008).

Spektrum elektromagnetik dapat dibagi ke dalam beberapa (sub) wilayah panjang gelombang. Salah satunya adalah spektrum sinar tampak (visible spectrum). Spektrum sinar tampak merupakan panjang gelombang yang sempit, berwarna dan cahaya yang dapat dideteksi atau dilihat oleh mata manusia, yaitu berkisar antara 0,4 $\mu \mathrm{m}$ hingga 0,7 $\mu \mathrm{m}$ (Prahasta, 2008).

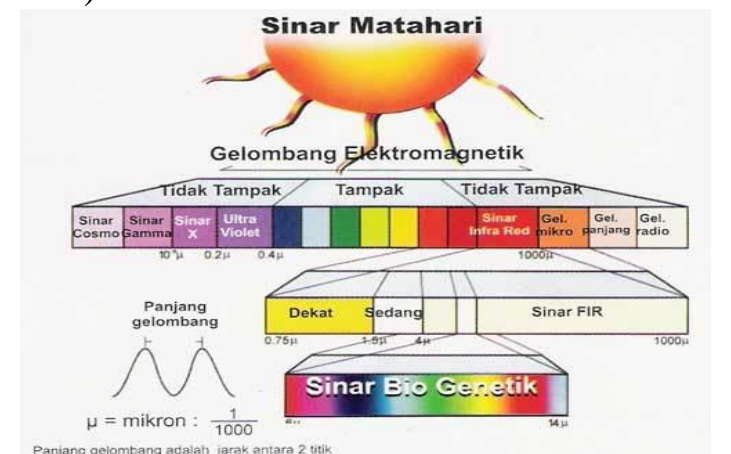

Gambar 1. Tampilan gambar spektrum elektromagnetik

Sebagaimana diketahui bahwa bagi material-material yang menjadi target sensor, jumlah radiasi sinar matahari yang dipantulkan, diserap, atau bahkan diteruskan kembali akan bervariasi sesuai dengan berapa panjang gelombang yang dipancarkan(Prahasta, 2008).

\section{Citra Satelit Landsat 8}

Landsat merupakan salah satu satelit yang digunakan untuk penginderaan jauh. Landsat yang sekarang telah mencapai generasi Landsat-8.Satelit 
Landsat-8 memiliki sensor Onboard Operational Land Imager (OLI) dan Thermal Infrared Sensor (TIRS) dengan jumlah kanal sebanyak 11 buah. Di antara kanal-kanal tersebut, 9 kanal (band 1-9) berada pada OLI dan 2 lainnya (band 10 dan 11) pada TIRS. Sebagian besar kanal memiliki spesifikasi mirip dengan Landsat-7 (Andana, 2015).

Tabel 1. Spesifikasi Kanal-kanal Spektral Sensor Pencitra LDCM (Landsat8)

\begin{tabular}{|c|c|c|c|}
\hline \multirow{12}{*}{$\begin{array}{l}\text { Landsat } \\
\text { 8OLIda } \\
\text { nTIRS }\end{array}$} & Band & $\begin{array}{l}\text { PanjangGel } \\
\text { ombang } \\
\text { (micromete } \\
\text { r) }\end{array}$ & $\begin{array}{l}\operatorname{Re} \\
\text { sol } \\
\text { usi } \\
\text { (m } \\
\text { ete } \\
\text { r) }\end{array}$ \\
\hline & $\begin{array}{l}\text { Band 1 - } \\
\text { Coastal } \\
\text { aerosol }\end{array}$ & $0,43-0,45$ & 30 \\
\hline & $\begin{array}{l}\text { Band } 2- \\
\text { Blue }\end{array}$ & $0.45-0,51$ & 30 \\
\hline & $\begin{array}{l}\text { Band } 3- \\
\text { Green }\end{array}$ & $0,53-0,59$ & 30 \\
\hline & $\begin{array}{l}\text { Band } 4 \quad- \\
\text { Red }\end{array}$ & $0,64-0,67$ & 30 \\
\hline & $\begin{array}{l}\text { Band } 5- \\
\text { Near } \\
\text { Infrared } \\
\text { (NIR) }\end{array}$ & $0,85-0,88$ & 30 \\
\hline & $\begin{array}{lll}\text { Band } 6 & - \\
\text { SWIR } 1 & \end{array}$ & $1,57-1,65$ & 30 \\
\hline & $\begin{array}{l}\text { Band } 7- \\
\text { SWIR } 2\end{array}$ & $2,11-2,29$ & 30 \\
\hline & $\begin{array}{l}\text { Band } 8- \\
\text { Panchromat } \\
\text { ic }\end{array}$ & $0,50-0,68$ & 15 \\
\hline & $\begin{array}{ll}\text { Band } 9- \\
\text { Cirrus }\end{array}$ & $1,36-1,68$ & 30 \\
\hline & $\begin{array}{l}\text { Band } 10- \\
\text { Thermal } \\
\text { Infrared } \\
\text { (TIRS) } 1\end{array}$ & $\begin{array}{l}10,60- \\
11,19\end{array}$ & $\begin{array}{l}10 \\
0\end{array}$ \\
\hline & $\begin{array}{l}\text { Band 11- } \\
\text { Thermal } \\
\text { Infrared } \\
\text { (TIRS) } 2\end{array}$ & $\begin{array}{l}11,50- \\
12,51\end{array}$ & $\begin{array}{l}10 \\
0\end{array}$ \\
\hline
\end{tabular}

Sumber: Landsat.usgs.gov, 2015.
Pada mulanya bernama ERTS-1 (Earth Resources Technology Satellite). Bersamaan dengan peluncuran ERTS-B tanggal 22 juli 1975, NASA (National Aeronautic and Space Administration) secara resmi mengubah program ERTS menjadi program Landsat(Loppies, 2010).

Satelit Landsat-8 telah berhasil diluncurkan NASA pada tanggal 11 Februari 2013 lalu bertempat di Vandenberg Air Force Base, California (Andana, 2015).

\section{IndeksVegetasi}

Indeks vegetasi adalah besaran nilai kehijauan vegetasi yang diperoleh dari pengolahan sinyal digital data nilai kecerahan (brightness) beberapa kanal data sensor satelit. Untuk pemantauan vegetasi, dilakukan proses perbandingan tingkat kecerahan kanal cahaya merah (red) dan infra merah dekat (near infra red/NIR). Penyerapan cahaya merah oleh klorofil dan pemantulan cahaya infra merah dekat oleh jaringan mesofil pada daun akan membuat nilai kecerahan yang diterima sensor satelit melalui band-band tersebut akan jauh berbeda. Pada daratan tanpa vegetasi, termasuk wilayah perairan dan pemukiman, lahan kosong terbuka, atau kondisi vegetasi yang rusak, tidak dapat memberikan nilai rasio yang tinggi pada perbandingan nilai kanal-kanal tersebut.Dan sebaliknya pada daratan dengan vegetasi yang rapat dan kondisi sehat, perbandingan nilai kedua kanal tersebut memberikan nilai yang sangat tinggi (Andana, 2015).

\section{Normalized Difference Vegetation Index (NDVI)}

Indeks vegetasi yang paling umum digunakan adalah Normalized Difference Vegetation Index (NDVI). Nilai indeks vegetasi ini didasarkan pada perbedaan antara penyerapan maksimum radiasi di band merah (red) sebagai hasil dari pigmen klorofil dan reflektansi maksimum di band spektral infra merah dekat (near infra red/NIR) sebagai akibat dari struktur selular daun. Hal ini menghasilkan kontras 
penyerapan yang kuat diband panjang gelombang sempit $650-850 \mathrm{~nm}$, ditangkap oleh NDVI. NDVI menormalkan nilai antara -1 sampai +1 , vegetasi padat memiliki NDVI tinggi, sementara nilai tanah yang rendah tetapi positif, dan air negatif karena penyerapan yang kuat dari NIR (Tucker dalam Andana, 2015).

Adapun formulasi NDVI adalah sebagai berikut:

NDVI $=\frac{(\rho \text { NIR }-\rho \text { Red })}{(\rho \text { NIR }+\rho \text { Red })} \ldots \ldots \ldots \ldots \ldots \ldots \ldots \ldots$.

Keterangan:

$\rho N I R=$ nilai reflektan band infra merah dekat

$\rho$ Red $=$ nilai reflektan band merah

\section{Soil Adjusted Vegetation Index (SAVI)}

(SAVI) merupakan algoritma pengembangan dari NDVI dengan menekan pengaruh latar belakang tanah pada tingkat kecerahan kanopi. SAVI menggunakan persamaan isoline vegetasi (vegetasi dengan kerapatan sama dan latar belakang tanah berbeda) yang diturunkan melalui aproksimasi reflektansi kanopi dengan sebuah model interaksi foton orde pertama antara kanopi dan lapisan tanah. Penurunan spektral campuran merah, arena tanahyang lebih gelap, menyebabkan peningkatan signifikan pada NDVI. NDVI nampak sensitif terhadap tanah yang menjadi lebih gelap akibat perkembagnan vegetasi (Huete dalam Andana, 2015).

Adapun formulasi SAVI adalah sebagai berikut:

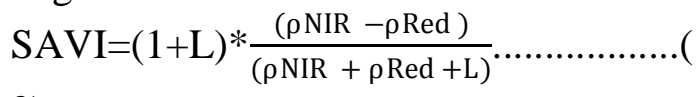

Keterangan:

$\rho \mathrm{NIR}=$ nilai reflektan band infra merah dekat

$\rho$ Red $=$ nilai reflektan band merah

$\mathrm{L}=$ koreksi pencerahan latar belakang tanah
Enhanched Vegetation Index (EVI)

Menurut Andana
Enhanched Vegetation Index
merupakan indeks vegetasi yang
dikembangkan untuk meminimalkan
pengaruh latar belakang kanopi dan variasi
atmosfir yang lebih baik dari NDVI. EVI
dihitung dengan menggunakan reflektan
dari band biru (blue), merah (red), dan
infra merah dekat (NIR), sehingga
diperoleh persamaan sebagai berikut:
EVI $=\mathrm{G} * \frac{\rho \mathrm{NIR}-\rho \mathrm{R}}{\rho \mathrm{NIR}+\mathrm{C} 1 * \rho \mathrm{R}-\mathrm{C} 2 * \rho B L U E+\mathrm{L}} . . . . . . . . . .($

Keterangan:

$\rho N I R=$ nilai reflektan band infra merah dekat

$\rho \mathrm{R}=$ nilai reflektan band merah

$\rho$ Blue $=$ nilai reflektan band biru

$\mathrm{C} 1=$ koefisien koreksi pengaruh atmosfir pada band merah

$\mathrm{C} 2=$ koefisien koreksi pengaruh atmosfir pada band biru

$\mathrm{L}=$ koreksi pencerahan latar belakang tanah

$\mathrm{G}=$ gain factor

\section{Analisis Regresi}

Korelasi dan regresi keduanya mempunyai hubungan yang sangat erat. Setiap regresi pasti ada korelasinya, tetapi korelasi belum tentu dilanjutkan dengan regresi. Korelasi yang tidak dilanjutkan dengan regresi, adalah korelasi antara dua variabel yang tidak mempunyai hubungan kasual/sebab akibat, atau hubungan fungsional. Untuk menetapkan kedua variabel mempunyai hubungan kusal atau tidak, maka harus didasarkan pada teori atau konsep-konsep tentang dua variabel tersebut. Kita gunakan analisis regresi bila kita ingin mengetahui bagaimana variabal dependen/kriteria dapat diprediksikan melalui variabel independen atu variabel prediktor, secara individual. Dampak dari penggunaan analisis regresi dapat digunakan untuk memutuskan apakah naik dan menurunnya variabel dependen dapat dilakukan melalui menaikan dan menurunkan keadaan variabel independen (Fadli, 2012). 
A. Regresi Linier Sederhana

Regresi sederhana didasarkan pada hubungan fungsional ataupun kausal antara satu variabel independen dengan satu variabel dependen. Persamaan umum regresi linier sederhana adalah :

$\mathrm{Y}=\mathrm{a}+\mathrm{bX}$

B. Regresi Ganda

Analisis regresi ganda digunakan oleh peneliti, bila peneliti bermaksud meramalkan bagaimana keadaan (naik turunnya) variabel dependen (kriterium), bila dua atau lebih variabel independen sebagai prediktor dimanipulasi (dinaikturunkan nilainya). Jadi analisis regresi ganda akan dilakukan bila jumlah variabel independennya minimal 2 .

Persamaan regresi untuk dua prediktor : $\mathrm{Y}=\mathrm{a}+\mathrm{b} 1 \mathrm{X} 1+\mathrm{b} 2 \mathrm{X} 2$

Persamaan regresi untuk tiga prediktor : $\mathrm{Y}=\mathrm{a}+\mathrm{b} 1 \mathrm{X} 1+\mathrm{b} 2 \mathrm{X} 2+\mathrm{b} 3 \mathrm{X} 3$

Persamaan regresi untuk $\mathrm{n}$ prediktor : $\mathrm{Y}=\mathrm{a}$ $+\mathrm{b} 1 \mathrm{X} 1+\mathrm{b} 2 \mathrm{X} 2+\ldots+\mathrm{bnXn}$.

\section{Koefisien Korelasi}

Korelasi adalah derajat hubungan linier antara dua variabel atau lebih dari data hasil pengamatan. Dua variabel dikatakan berkorelasi apabila perubahan dalam satu variabel diikuti oleh perubahan variabel lain, baik yang searah maupun tidak. Makin kecil koefisien korelasi, maka akan semakin besar error untuk membuat prediksi (Fadli, 2012).

Berdasarkan hubungan antar variabel yang satu dengan variabel lainnya dinyatakan dengan koefisien korelasi yang disimbolkan dengan "r". Besarnya koefisien korelasi dapat diketahui berdasarkan penyebaran titik-titik pertemuan antara dua variabel misalnya $X$ dan Y. Besarnya korelasi berkisar antara $1 \leq \mathrm{r} \leq 1$. Bila titik-titik itu membentuk lingkaran, maka koefisien korelasinya $=1$ atau -1. Bila titik-titik itu membentuk lingkaran, maka koefisien korelasinya $=0$ (Fadli, 2012).

\section{Koefisien Determinasi}

Dalam analisis korelasi terdapat suatu angka yang disebut dengan koefisien determinasi, yang besarnya adalah kuadrat dari koefisien korelasi $\left(\mathrm{R}^{2}\right)$. Koefisien tersebut disebut sebagai koefisien penentu, karena varians yang terjadi pada variabel dependen (variabel tak bebas) dapat dijelaskan melalui variabel independent (variabel bebas). Nilai $\mathrm{R}^{2}$ dikatakan baik jika berada di atas 0,5 karena nilai $\mathrm{R}^{2}$ berkisarantara 1 dan 1 (Fadli, 2012).

Maka akan ditentukan dengan rumus:

$\mathrm{R}^{2}=\frac{\mathrm{b}_{1} \sum \mathrm{x}_{1 \mathrm{i}} \mathrm{y}_{\mathrm{i}}+\mathrm{b}_{2} \sum \mathrm{x}_{2 \mathrm{i}} \mathrm{y}_{\mathrm{i}}+\cdots+\mathrm{b}_{\mathrm{k}} \sum \mathrm{x}_{\mathrm{ki}} \mathrm{y}_{\mathrm{i}}}{\Sigma\left(\mathrm{Y}_{\mathrm{I}}-\mathrm{Y}_{\mathrm{I}}\right)^{2}}$

Sehingga rumus umum koefisien determinasi yaitu:

$\mathrm{R}^{2}=\frac{J K_{\text {reg }}}{\sum_{i=1}^{n} Y_{i}^{2}}$

Keterangan:

$\mathrm{JK}_{\text {reg }}=$ Jumlah kuadrat regresi

\section{Tanaman Hortikultura}

Pengertian hortikultra ditinjau dari Kamus Besar Bahasa Indonesia memiliki beberapa pengertian, yaitu pengusaha dan pemeliharaan kebun bunga, buah-buahan, dan sayur-sayuran. Kata Hortikultura (Horticulture) berasal dari Bahasa Latin 'hortus' yang artinya kebun dan 'colere' yang artinya membudidayakan. Jadi hortikultura adalah membudidayakan tanaman di kebun (Irwan, 2014).

Berdasarkan jenis tanaman yang diusahakan, hortikultura mencakup bidang ilmu: Pomologi (Pomology) yang mempelajari buah-buah, Olerikultur (Olericulture) yang mempelajari sayursayuran, Florikultur (Floriculture) yang mempelajari bunga dan tanaman hias, Biofarmaka yang mempelajari tanaman obat. Istilah tersebut tidak terbatas penggunaannya, bisa fleksibel, dapat berlaku sesuai dengan fungsinya (Irwan, 2014).

Dari pengertian tersebut, hortikultura dapat dikatakan sebagai ilmu yang mempelajari tentang peningkatan produk tanaman perkebunan. Tanama perkebunan ada beberapa jenis diantaranya 
ialah tanaman sayuran dan buah-buahan. Dalam pengembangbiakan tanaman tersebut, harus diperhatikan beberapa hal diantaranya sistem yang akan digunakan, penggunaan bibit unggul, kadar air tanah, jenis tanaman yang akan dibudidayakan, dan beberapa komponen lainnya (Irwan, 2014).

\section{Peta Kontur}

Dalam peta kontur lengas tanah, informasi tentang kadar lengas tanah biasanya berupa garis kontur, yaitu garis yang menghubungkan titik-titik dengan kadar lengas tanah yang sama. Berdasarkan model/motif dari kumpulan garis kontur tersebut, bisa diketahui keadaan sebenarnya di lapangan. Interval kontur merupakan perbedaan lengas tanah antar dua garis kontur yang berdekatan. Dalam hal penyajian, semakin besar skala maka informasi pada peta akan semakin banyak (semakin detail), sehingga interval kontur akan semakin kecil. Indeks kontur lengas tanah merupakan garis kontur dengan kelipatan tertentu. Sifat-sifat dari garis kontur ada beberapa macam diantaranya: garis kontur saling melingkari satu sama lain, tidak akan saling berpotongan, bisa berimpit, garis kontur menutup pada dirinya sendiri, tidak mungkin bercabang dan kontur selalu menutup bentuknya. Menutupnya dapat di dalam muka peta ataupun di luar. Jika menutupnya di luar, maka pada muka peta terlihat kontur itu tidak menutup (Ismail, 2010).

\section{METODOLOGI PENELITIAN}

\section{Waktu dan Tempat}

Penelitian mengenai "Pendugaan Lengas TanahPadaTanamanHortikultura Menggunakan Citra Landsat 8" dilaksanakan pada bulan Oktober 2016 hingga bulan November 2016, mengikuti periode satelit Landsat 8 lewat di Wilayah Kelurahan Bajeng, Kecamatan Patalassang, Kabupaten Takalar.

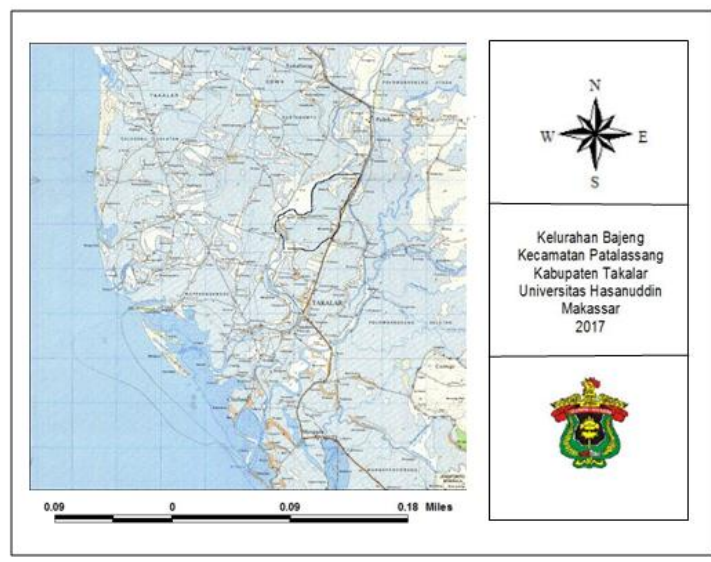

Gambar 2. Petalokasipenelitian

\section{Alat dan Bahan}

Alat yang digunakan pada penelitian ini adalah laptop, software pengolah data, sekop kecil, plastik sampel, timbangan, GPS, meteran, patok bambu, wadah aluminium dan oven.

Bahan yang digunakan adalah Citra Satelit Landsat-8 TM Kabupaten Takalardan peta rupa bumi.

\section{Metode Penelitian}

Prosedur penelitian ini adalah sebagai berikut:

\section{Pengumpulan Data}

Penelitian ini didahului dengan pengumpulan bahan penelitian berupa data-data masukan atau input yang diperlukan.

\section{Data Primer}

Data primer merupakan data yang didapatkan melalui hasil observasi langsung di lapangan yaitu informasi mengenai kadar lengas tanah lapangan di beberapa titik pengamatan.

\section{Data Sekunder}

Data sekunder merupakan data yang didapatkan melalui dinas-dinas terkait seperti data citra Landsat 8 yang diunduh melalui USGS, peta jenia tanah inceptisol dan peta rupa bumi Indonesia.

\section{Perhitungan Kadar Lengas Tanah}

Metode gravimetrik adalah metode yang sederhana secara konseptual untuk 
mengetahui kadar air tanah. Pada prinsipnya mencakup pengukuran kehilangan air dengan menimbang contoh tanah sebelum dan sesudah dikeringkan pada suhu $105-110{ }^{\circ} \mathrm{C}$ dalam oven. Hasilnya dinyatakandalam presentase air dalam tanah, yang dapat diekspresikan dalam presentase terhadap berat keringatau berat basah.

Menurut Abdurachman, dkk (2015), masing-masing dari presentase berat ini dapat dihitung dengan menggunakan persamaan sebagai berikut:

1. $\% \mathrm{H}_{2} \mathrm{O}$ berat kering $=\left(\right.$ berat $\mathrm{H}_{2} \mathrm{O} /$ berat tanah kering oven ) $\mathrm{x}$ $100 \%$.........................(3.1)

2. $\% \mathrm{H}_{2} \mathrm{O}$ berat basah $=$ (berat $\mathrm{H}_{2} \mathrm{O} /$ berat basah tanah)

$100 \%$ (3.2)

\section{Cropping}

Cropping bertujuan untuk memotong citra sesuai dengan batas administrasi daerah penelitian atau dapat dikatakan sebagai pembatasan wilayah. Hal ini bertujuan untuk mempermudah dalam menganalisa citra dan agar dapat melakukan pengolahan data yang lebih terfokus, terinci, dan teroptimal. Pada penelitian ini, digunakan citra Landsat 8 yang dapat di unduh dari web http://earthexplorer.usgs.gov/. Pembatasan atau pemotongan citra dilakukan dengan menggunakan software pengolah data.

\section{Perhitungan Indeks Vegetasi}

1. Normalized Difference Vegetation Index (NDVI)

Indeks vegetasi ini didasarkan pada perbedaan antara penyerapan maksimum radiasi di band merah (red) sebagai hasil dari pigmen klorofil dan reflektansi maksimum di band spektral infra merah dekat (near infra red / NIR) sebagai akibat dari struktur seluler daun. Adapun formulasi NDVI dapat dilihat pada persamaan (2.1).

2. Soil Adjusted Vegetation Index (SAVI)
Soil Adjusted Vegetation Index (SAVI) merupakan algoritma pengembangan dari NDVI dengan menekan pengaruh latar belakang tanah pada tingkat kecerahan kanopi. Penurunan spektra campuran merah, area tanah yang lebih gelap, menyebabkan peningkatan signifikan pada NDVI. Adapun formulasi SAVI dapat dilihat pada persamaan (2.2).

3. Enhanched Vegetation Index (EVI)

Enhanched Vegetation Index (EVI) merupakan indeks vegetasi yang dikembangkan untuk meminimalkan pengaruh latar belakang kanopi dan variasi atmosfir yang lebih baik dari NDVI. EVI dihitung dengan menggunakan reflektan dari band biru, merah, dan infra merah dekat (NIR). Persamaannya dapat dilihat pada persamaan (2.3).

\section{Koreksi Radiometrik}

Data Landsat 8 dikoreksi radiometrik menggunakan koreksi ToA yang meliputi Top of Atmosphere (ToA) reflektansidan koreksi matahari.Koreksi ToA reflektansi dilakukan dengan mengkonversi nilai DN ke nilai reflektansi. Berdasarkan (Rahayu, 2014), persamaan konversi untuk koreksi ToA reflektansi yaitu:

$\rho \lambda^{\prime}=M_{p} Q c a l+A p$

Keterangan:

$\rho \lambda^{\prime}=$ ToA reflektansi, tanpa koreksi untuk sudut matahari .

$M_{p}=$ REFLECTANCE_MULT_BAND_x , di mana $\mathrm{x}$ adalah nomor Band

$A p=$ REFLECTANCE_ADD_BAND_x , di mana $\mathrm{x}$ adalah nomor Band

Qcal $=$ Digital Number $(\mathrm{DN})$

Selanjutnya citra dikoreksi sudut matahari untuk menghilangkan perbedaan nilai DN yangdiakibatkan oleh posisi matahari.Posisi matahari terhadap bumi berubah bergantung pada waktuperekaman dan lokasi obyek yang direkam. Persamaan untuk koreksi dengan sudut matahari yaitu: $\rho \lambda=$ $\rho \lambda^{\prime} /\left(\sin \left(\theta_{\mathrm{SE}}\right)\right) \ldots \ldots .(3.4)$ $\rho \lambda^{\prime} /\left(\cos \left(\theta_{\mathrm{SZ}}\right)\right)=$ Keterangan: 
$\rho \lambda=$ ToA reflektansi setelah koreksi

matahari

$\theta_{\mathrm{SE}}=$ sun elevation

$\theta_{\mathrm{SZ}}=$ sudut zenith matahari, $\theta_{\mathrm{SZ}}=90^{\circ}-\theta_{\mathrm{SE}}$

\section{Transformasi Reflektansi}

Menurut Wouthuyzen (2008), transformasi reflektansi yang digunakan adalah band 2 (biru), band 3 (hijau), dan band 4 (merah).Rasio band yang digunakan menyesuaikan panjanggelombang rasio band dalam penelitian. Sehingga pada pengolahan citra Landsat 8 transformasi reflektansi sebagai berikut:

a. Kromatisasi biru $(\mathrm{KB})=\frac{\mathrm{B} 2}{\mathrm{~B} 2+\mathrm{B} 3+\mathrm{B} 4} \ldots . .(3.5)$

b. Kromatisasi hijau $(\mathrm{KH})=\frac{\mathrm{B} 3}{\mathrm{~B} 2+\mathrm{B} 3+\mathrm{B} 4}$...(3.6)

c. Kromatisasi

merah

$$
(\mathrm{KM})=\frac{\mathrm{B} 4}{\mathrm{~B} 2+\mathrm{B} 3+\mathrm{B} 4} . .(3.7)
$$

\section{Fungsi Prediksi}

Pada tahap ini, dilakukan pendugaan atau prediksi yang memberikan penjelasan tentang pola hubungan (model) antara dua variabelatau lebih yaitu antara komponen data citra dengan kadar lengas tanah.

Analisis Hubungan Antara Komponen Data Citra Landsat 8 Dengan Kadar Lengas Tanah

Pada tahap ini, dilakukan analisis korelasi atau analisis hubungan antara komponen data citra Landsat 8 dengan kadar air tanah (lengas tanah) hasil pengukura lapangan menggunakan metode korelasi.

\section{Output}

Output penelitian ini berupa algoritma fungsi pendugaan lengas tanah dan peta prediksi lengas tanah

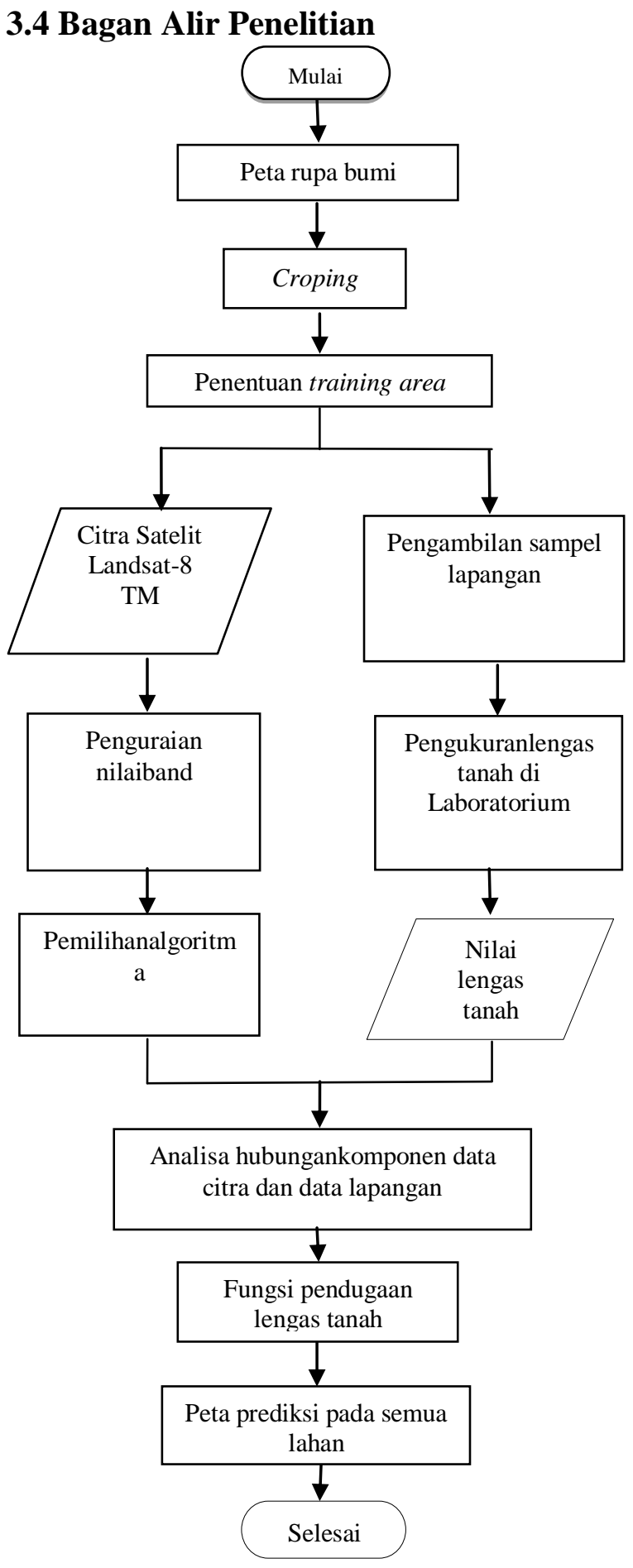

Gambar 3. Bagan Alir Penelitian

HASIL DAN PEMBAHASAN

\section{Pengembangan Model Pendugaan}

Kadar Lengas Tanah Menggunakan Citra Landsat 8

Model pendugaan yang terbaik untuk menduga kadar lengas tanah dengan menggunakan komponen data citra dapat 
diperoleh melalui simulasi model regresi linier atau non linier terhadap variabel tidak bebas maupun variabel bebas (prediktor) untuk memperoleh hasil yang optimal dalam menduga variabel tidak bebas. Dari penelitian ini, diharapkan ditemukan suatu model pendugaan kadar lengas tanah. Pembuatan model algoritma diharapkan dapat mempermudah dalam melakukan pemetaan kelengasan tanah dengan cakupan wilayah yang luas, tanpa menggunakan biaya yang besar dan waktu yang lama.

Umumnya nilai pantulan atau radiasi bersifat khusus apabila suatu objek diindera. Pantulan spektral akan memberikan kenampakan yang berbedabeda pada setiap objek yang tampak di permukaan bumi dan sekaligus dalam setiap hasil perekaman tersebut memiliki nilai spektral yang dapat diolah secara digital untuk memberikan informasi yang baru. Menurut Petropoulos (2013), ilmu iklim yang berasal dari satelit dan permodelan pengamatan lengas tanah in situ dapat sangat berbeda dikarenakan ketidaktentuan sumber data dari keduanya.

\section{Model algoritma pendugaan kadar lengas tanah menggunakan reflektansi band tunggal pada citra Landsat 8}

Dalam membangun algoritma pendugaan antara kadar lengas tanah dengan komponen data citra Landsat 8 terdapat beberapa pertimbangan, diantaranya dalam memilih lokasi atau titik sampel pengamatan. Dipilih lokasi yang memiliki kadar lengas tanah yang berbeda-beda dan jarak antar lokasi \pm 100 $\mathrm{m}$. Pengambilan sampel tanah lapangan dilakukan dengan mengambil sampel tanah inceptisol terganggu pada lapisan tipis tanah $( \pm 10 \mathrm{~cm})$ dari permukaan tanah. Jenis tanah inceptisol yang diambil memiliki warna tanah 3/2 2,5 Y hue, yaitu very dark grayish brown. Seperti yang dijelaskan oleh Petropoulos (2013), yang menyatakan bahwa sensor satelit hanya mampu memantau lapisan tanah yang sangat tipis, informasi soil moisture atau lengas tanah yang diberikan sulit berasimilasi ke dalam model hidrologi dan meteorologi.

Pada penelitian ini, digunakan beberapa band atau kanal pada citra Landsat 8 diantaranya band 2 (biru; 0,45$0,51 \mu \mathrm{m}$ ), band 3 (hijau; 0,5-0,59 $\mu \mathrm{m}$ ), band 4 (merah; 0,64-0,67 $\mu \mathrm{m}$ ), dan band 5 (inframerah dekat/NIR; 0,85-0,88 $\mu \mathrm{m}$ ). Hal tersebut dikarenakan band 2, 3, dan 4 merupakan band tampak. Pada panjang gelombang tampak mata, pigmentasi (zat pewarna daun) mendominasi respon spektral vegetasi. Pada panjang gelombang infra merah dekat pantulan vegetasi naik dengan jelas sebab daun menyerap tenaga sangat sedikit.

Tabel 2. Model algoritma pendugaan kadar lengas tanah menggunakan reflektansi band tunggal pada citra Landsat 8

\begin{tabular}{lll}
\hline $\begin{array}{l}\text { No. Kanal } \\
\text { Tunggal }\end{array}$ & Fungsi & $\mathbf{R}^{2}$ \\
\hline
\end{tabular}

1. Band $\mathrm{LT}=-130.2(\mathrm{~B} 2)^{2}+\mathrm{R}^{2}=$ $2 \quad 114.0(\mathrm{~B} 2)+11.08 \quad 0,653$

2. Band $\mathrm{LT}=-144.9(\mathrm{~B} 3)^{2}+\mathrm{R}^{2}=$ $3 \quad 121.3(\mathrm{~B} 3)+11.34 \quad 0,650$

3. Band $\mathrm{LT}=-167 \cdot 1(\mathrm{~B} 4)^{2}+\mathrm{R}^{2}=$ $4 \quad 114.4(\mathrm{~B} 4)+15.02 \quad 0,461$

4. Band $\mathrm{LT}=-8.429(\mathrm{~B} 5)^{2}+\mathrm{R}^{2}=$ $5 \quad 25.32(\mathrm{~B} 5)+16.26 \quad 0,484$

Hubungan terbaik yang diperoleh antara komponen data citra band tunggal dan lengas tanah adalah band 2 biru dengan $\mathrm{R}^{2}=0,653$. Dapat dikatakan pula bahwa hubungan yang terbentuk cukup kuat. Hal tersebut dikarenakan band 2 biru dapat menganalisis sifat khas lahan, tanah, dan vegetasi tergantung dari panjang gelombang yang dihasilkan.

\section{Model algoritma pendugaan kadar lengas tanah menggunakan indeks vegetasi pada citra Landsat 8}

Indeks vegetasi adalah besaran nilai kehijauan vegetasi yang diperoleh dari pengolahan sinyal digital data nilai 
kecerahan (brightness) beberapa kanal data sensor satelit. Terdapat berbagai fungsi atau formula tentang indeks vegetasi diantaranya: Normalized Difference Vegetation Index (NDVI), Soil Adjusted Vegetation Index (SAVI), dan Enhanched Vegetation Index (EVI). Dari ketiga indeks tersebut, terdapat beberapa perbedaan.

Tabel 3. Model algoritma pendugaan kadar lengas tanah menggunakan indeks vegetasi pada citra Landsat 8

\begin{tabular}{|c|c|c|}
\hline $\begin{array}{l}\text { No. Indeks } \\
\text { Vegetasi }\end{array}$ & Fungsi & $\mathbf{R}^{2}$ \\
\hline 1. NDVI & $\begin{array}{l}\mathrm{LT}=-5 \mathrm{E}+06\left(\frac{\mathrm{B} 5-\mathrm{B} 4}{\mathrm{~B} 5+\mathrm{B} 4}\right)^{3} \\
+30274\left(\frac{\mathrm{B} 5-\mathrm{B} 4}{\mathrm{~B} 5+\mathrm{B} 4}\right)^{2}- \\
4100\left(\frac{\mathrm{B} 5-\mathrm{B} 4}{\mathrm{~B} 5+\mathrm{B} 4}\right)+41.85\end{array}$ & $\begin{aligned} 3 & \mathrm{R}^{2} \\
& =0,079\end{aligned}$ \\
\hline 2. SAVI & $\begin{array}{l}\mathrm{LT}=357.8((1,5) * \\
\left.\frac{\mathrm{B} 5-\mathrm{B} 4}{\mathrm{~B} 5+\mathrm{B} 4+0,5}\right)^{3}- \\
427.5((1,5) * \\
\left.\frac{\mathrm{B} 5-\mathrm{B} 4}{\mathrm{~B} 5+\mathrm{B} 4+0,5}\right)^{2}+ \\
148.9((1,5) * \\
\left.\frac{\mathrm{B} 5-\mathrm{B} 4}{\mathrm{~B} 5+\mathrm{B} 4+0,5}\right)+19.73\end{array}$ & $\begin{array}{l}\mathrm{R}^{2} \\
=0,843\end{array}$ \\
\hline
\end{tabular}

3. EVI

$$
\begin{aligned}
& \mathrm{LT}=6 \mathrm{E}+08\left(2,5 * \quad \mathrm{R}^{2}\right. \\
& \left.\frac{\mathrm{B} 5-\mathrm{B} 4}{\mathrm{~B} 5+6 * \mathrm{~B} 4-7,5 * \mathrm{~B} 2+0,5}\right)^{3}- \\
& 7 \mathrm{E}+06(2,5 * \\
& \left.\frac{\mathrm{B} 5-\mathrm{B} 4}{\mathrm{~B} 5+6 * \mathrm{~B} 4-7,5 * \mathrm{~B} 2+0,5}\right)^{2} \\
& +21649(2,5 * \\
& \left.\frac{\mathrm{B} 5-\mathrm{B} 4}{\mathrm{~B} 5+6 * \mathrm{~B} 4-7,5 * \mathrm{~B} 2+2,5}\right)+
\end{aligned}
$$

17.85

NDVI merupakan salah satu indeks vegetasi yang hanya menggunakan dua jenis band tunggal untuk mendapatkan suatu nilai indeks vegetasi, yaitu band 4 dan band 5 Menurut Andana (2015), nilai indeks vegetasi ini didasarkan pada perbedaan antara penyerapan maksimum radiasi di band 4 sebagai hasil dari pigmen klorofil dan reflektansi maksimum di band spektral infra merah dekat sebagai akibat dari struktur selular daun. Pada penelitian ini, nilai NDVI tidak menunjukkan hasil yang signifikan, hal ini disebabkan kombinasi band 4 merah dan band 5 tidak sensitif dengan vegetasi yang jarang. Lokasi penelitian ini memiliki vegetasi yang jarang, hal tersebut dikarenakan sebahagian besar lahan tersebut hanya ditanami tanaman seperti cabai, tomat, labu dan semangka yang tidak memiliki jumlah daun yang rimbun (lebat) serta jarak tanam yang tidak rapat. Karena hal tersebut, maka reflektansi pada band 4 sebagai hasil dari pigmen klorofil dan band 5 sebagai akibat dari struktur selular daun tidak maksimal. Hasil penelitian Domiri (2005), tentang pendugaan kelengasan tanah terhadap data satelit Terra/Aqua MODIS menunjukkan bahwa hasil korelasi yang tinggi antara Normalized Difference Vegetation Index (NDVI) dengan kadar air tanah (soil moisture) yaitu sebesar $\mathrm{R}^{2}=0,6986$ atau sebesar $69,86 \%$.

Enhanched Vegetation Index (EVI) merupakan indeks vegetasi yang dikembangkan untuk meminimalkan pengaruh latar belakang kanopi dan variasi atmosfir yang lebih baik dari NDVI. EVI dihitung dengan menggunakan reflektan dari band 2, 4, dan 5. Pada EVI juga dihitung nilai koefisien koreksi pengaruh atmosfir pada band $4(\mathrm{C} 1=6)$ dan band 2 $(\mathrm{C} 2=7,5)$, gain factor $(\mathrm{G}=2,5)$ dan koreksi pencerahan latar belakang tanah yang besarnya 0 untuk vegetasi yang sangat rapat dan 1 untuk vegetasi yang sangat 
jarang. Nilai 0,5 dipilih karena dapat bekerja dengan baik dalam kebanyakan situasi. Pada penelitian ini, nilai EVI yang didapatkan masih rendah atau dapat dikatakan bahwa EVI tidak memiliki pengaruh yang signifikan terhadap kadar lengas tanah.

Hubungan terbaik yang diperoleh antara indeks vegetasi dengan lengas tanah adalah Soil Adjusted Vegetation Index (SAVI) dengan nilai $\mathrm{R}^{\mathbf{2}}=0,843$. Hal tersebut menunjukkan bahwa hubungan antara SAVI dalam memprediksi kadar lengas tanah adalah sebesar $84,3 \%$ dan dapat dikatakan bahwa hubungan yang terbentuk cukup kuat. Dapat dikatakan pula bahwa terjadi hubungan positif antara keduanya. SAVI didasarkan pada perbedaan antara penyerapan maksimum radiasi di band 4 dan reflektansi maksimum di band 5 dan juga memperhitungkan nilai $\mathrm{L}$ atau koreksi latar belakang tanah.

Domiri (2005) menyimpulkan bahwa SAVI merupakan algoritma pengembangan dari NDVI dengan menekan pengaruh latar belakang tanah pada tingkat kecerahan kanopi. SAVI menggunakan persamaan isoline vegetasi (vegetasi dengan kerapatan sama dan latar belakang tanah berbeda). Penurunan spektra campuran merah, arena tanah yang lebih gelap, menyebabkan peningkatan signifikan pada NDVI. NDVI nampak sensitif terhadap tanah yang menjadi lebih gelap akibat perkembangan vegetasi. Hal tersebut menjadi salah satu alasan mengapa SAVI dapat menunjukkan hubungan yang baik dengan kadar lengas tanah. Seperti yang dijelaskan oleh Prahasta (2008), bahwa gangguan latar belakang tanah adalah gangguan berupa variasi respons spektral tanah yang berbeda-beda, yang menyebabkan kurang akuratnya indeks vegetasi yang dihasilkan. Pada garis tanah, terdapat bermacammacam vektor piksel tanah dengan kelembapan dan mungkin juga warna yang berbeda-beda, maka dari itu perlu dilakukan perhitungan Soil Adjusted

Vegetation Index (SAVI) untuk mengetahui perbedaannya.

\section{Model algoritma pendugaan kadar lengas tanah menggunakan transformasi kromatisasi pada citra Landsat 8}

Pengujian hubungan antara komponen data citra Landsat 8 dengan transformasi kromatisasi diantaranya kromatisasi biru, hijau, dan merah memperlihatkan hubungan yang terbaik yang diperoleh adalah hubungan antara kadar lengas tanah dengan kromatisasi hijau dengan nilai $\mathrm{R}^{2}=0,576$. Hal ini menunjukkan bahwa nilai dalam memprediksi kadar lengas tanah lapangan adalah sebesar 57,6\%. Kromatisasi hijau menggunakan tiga band atau kanal tunggal citra Landsat 8 diantaranya band 2, band 3 , dan band 4 .

Tabel 4. Model algoritma pendugaan kadar lengas tanah menggunakan transformasi kromatisasi pada citra Landsat 8

\begin{tabular}{|c|c|c|}
\hline No. & $\begin{array}{l}\text { Transformas } \\
\text { Kromatisasi }\end{array}$ & Fungsi \\
\hline & $\begin{array}{l}\text { Kromatisasi } \\
\text { Biru (KB) }\end{array}$ & $\begin{array}{l}\mathrm{LT}=- \\
6 \mathrm{E}+10\left(\frac{\mathrm{B} 2}{\mathrm{~B} 2+\mathrm{B} 3+\mathrm{B} 4}\right)^{3} 0,491 \\
+ \\
6 \mathrm{E}+10\left(\frac{\mathrm{B} 2}{\mathrm{~B} 2+\mathrm{B} 3+\mathrm{B} 4}\right)^{2} \\
-2 \mathrm{E}+10 \\
\left(\frac{\mathrm{B} 2}{\mathrm{~B} 2+\mathrm{B} 3+\mathrm{B} 4}\right)+ \\
2 \mathrm{E}+09\end{array}$ \\
\hline & $\begin{array}{l}\text { Kromatisasi } \\
\text { Hijau }(\mathrm{KH})\end{array}$ & $\begin{array}{l}\mathrm{LT}= \\
2 \mathrm{E}+10\left(\frac{\mathrm{B} 3}{\mathrm{~B} 2+\mathrm{B} 3+\mathrm{B} 4}\right)^{3} 0,576 \\
- \\
2 \mathrm{E}+10\left(\frac{\mathrm{B} 3}{\mathrm{~B} 2+\mathrm{B} 3+\mathrm{B} 4}\right)^{2} \\
+ \\
8 \mathrm{E}+09\left(\frac{\mathrm{B} 3}{\mathrm{~B} 2+\mathrm{B} 3+\mathrm{B} 4}\right) \\
-9 \mathrm{E}+08\end{array}$ \\
\hline & $\begin{array}{l}\text { Kromatisasi } \\
\text { Merah (KM) }\end{array}$ & $\begin{array}{l}\mathrm{LT}=- \\
4 \mathrm{E}+11\left(\frac{\mathrm{B} 4}{\mathrm{~B} 2+\mathrm{B} 3+\mathrm{B} 4}\right)^{3} 0,344 \\
+ \\
4 \mathrm{E}+11\left(\frac{\mathrm{B} 4}{\mathrm{~B} 2+\mathrm{B} 3+\mathrm{B} 4}\right)^{2}\end{array}$ \\
\hline
\end{tabular}




$$
\begin{aligned}
& 1 \mathrm{E}+11\left(\frac{\mathrm{B} 4}{\mathrm{~B} 2+\mathrm{B} 3+\mathrm{B} 4}\right) \\
& +1 \mathrm{E}+10
\end{aligned}
$$

Dari ketiga bentuk hubungan yang diuji dengan kadar lengas tanah baik pada band tunggal, indeks vegetasi, dan kromatisasi band maka diperoleh model algoritma yang memberikan nilai korelasi tertinggi, yaitu band 2 pada band tunggal, SAVI pada indeks vegetasi dan kromatisasi hijau pada transformasi kromatisasi. Transformasi polinomial digunakan karena mampu menghilangkan distorsi skala, translasi, rotasi dan skew.

$$
\begin{aligned}
& \mathrm{LT}=-130.2(\mathrm{~B} 2)^{2}+114.0(\mathrm{~B} 2)+ \\
& \text { 11.08.....(4.1) } \\
& \mathrm{LT}=324.6\left((1,5) * \frac{\mathrm{B} 5-\mathrm{B} 4}{\mathrm{~B} 5+\mathrm{B} 4+0,5}\right)^{3}- \\
& 387.7\left((1,5) * \frac{\mathrm{B} 5-\mathrm{B} 4}{\mathrm{~B} 5+\mathrm{B} 4+0,5}\right)^{2}+135.5((1,5) * \\
& \left.\frac{\mathrm{B} 5-\mathrm{B} 4}{\mathrm{~B} 5+\mathrm{B} 4+0,5}\right)+20.78 \text {. } \\
& \mathrm{LT} \quad=2 \mathrm{E}+10\left(\frac{\mathrm{B} 3}{\mathrm{~B} 2+\mathrm{B} 3+\mathrm{B} 4}\right)^{3} \\
& 2 \mathrm{E}+10\left(\frac{\mathrm{B} 3}{\mathrm{~B} 2+\mathrm{B} 3+\mathrm{B} 4}\right)^{2}+8 \mathrm{E}+09\left(\frac{\mathrm{B} 3}{\mathrm{~B} 2+\mathrm{B} 3+\mathrm{B} 4}\right)- \\
& 8 \mathrm{E}+08 \text {. }
\end{aligned}
$$

Plot titik antara nilai band 2 dengan lengas tanah disajikan pada Gambar 5, plot titik antara nilai reflektansi Soil Adjusted Vegetation Index (SAVI) dengan nilai lengas tanah disajikan pada Gambar 6 sedangkan plot titik antara nilai reflektansi kromatisasi hijau dengan nilai lengas tanah disajikan pada Gambar 7.

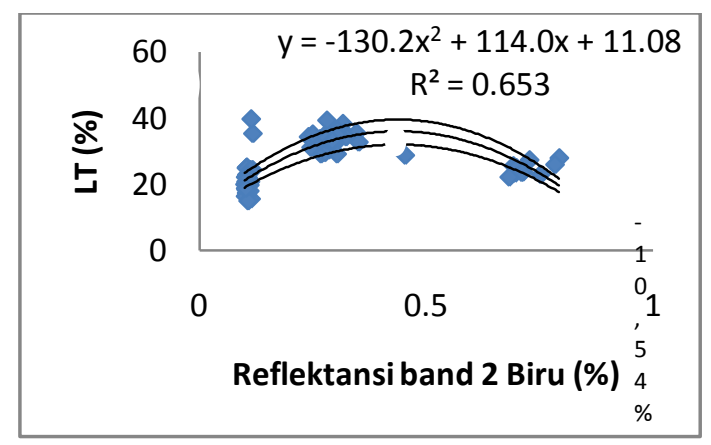

Gambar 4. Grafik hubungan antara reflektansi band 2 biru citra Landsat 8 dengan lengas tanah

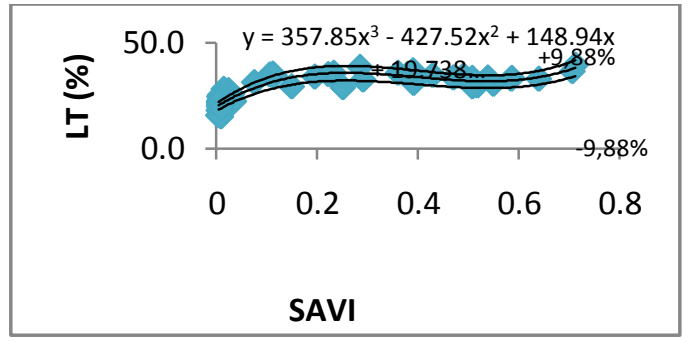

Gambar 5. Grafik hubungan antara SAVI citra Landsat 8 dengan lengas tanah

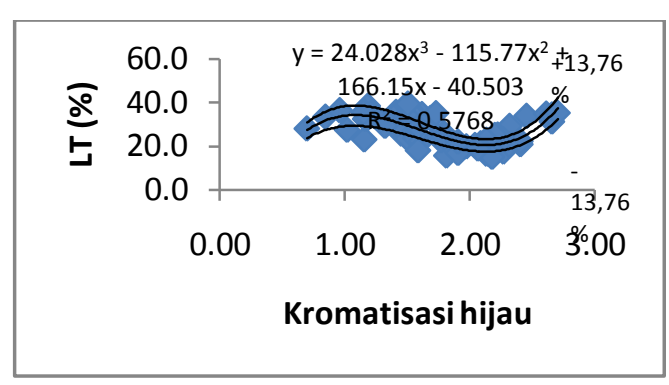

Gambar 6. Grafik hubungan antara kromatisasi hijau citra Landsat 8 dengan lengas tanah

Gambar 5 memperlihatkan hubungan antara reflektansi band 2 biru dengan lengas tanah memiliki $\mathrm{R}^{2}=0,653$. Hal ini menunjukkan bahwa keragaman variabel mempengaruhi sebesar 65,3\% sedangkan sisanya dipengaruhi oleh variabel lain yang tidak masuk dalam model. Gambar 6 memperlihatkan hubungan antara SAVI dengan lengas tanah memiliki nilai $\mathrm{R}^{2}=0,843$. Hal ini menunjukkan bahwa keragaman variabel mempengaruhi sebesar $84,3 \%$ sedangkan sisanya dipengaruhi oleh variabel lain yang tidak masuk dalam model. Pada Gambar 6 menunjukkan bahwa hubungan antara kromatisasi hijau dengan lengas tanah memiliki nilai $\mathrm{R}^{2}=0,576$. Hal ini menunjukkan bahwa keragaman variabel mempengaruhi sebesar 57,6\%.

Selain itu, $+10,54 \%$ a band 2, hubungan yang terbentuk berkorelasi negatif akan tetapi untuk SAVI dan kromatisasi hijau berkorelasi positif. Garis regresi yang terbentuk juga mengikuti plot data walaupun terdapat beberapa data yang menyimpang jauh dari data yang lainnya dalam suatu rangkaian data yang disebut sebagai outlier. Data outlier membuat analisis terhadap serangkaian data menjadi 
bias atau tidak mencerminkan fenomena yang sebenarnya. Data outlier dapat disebabkan karena adanya pengaruh awan atau pun lokasi yang tidak memiliki vegetasi sehingga kurang maksimalnya reflektansi cahaya pada data citra.

Terdapat 3 garis trendline dimana garis bagian atas merupakan garis yang menunjukkan penambahan nilai error sedangkan garis bawah menunjukkan pengurangan nilai error. Nilai error menunjukkan selisih antara nilai duga (predicted value) dengan nilai pengamatan yang sebenarnya apabila data yang digunakan adalah data sampel. Nilai erroruntuk band $2 \pm 10,54$, SAVI $\pm 9,88 \%$ dan untuk kromatisasi hijau $\pm 13,76 \%$. Nilai error tersebut didapatkan dari perhitungan absolute error dan relative error antara lengas tanah ukur dan lengas tanah fungsi. Absolute error atau kesalahan mutlak dari suatu bilangan adalah nilai mutlak dari selisih antara nilai sebenarnya dengan suatu nilai pendekatan pada nilai sebenarnya. Kesalahan relative adalah perbandingan antara kesalahan mutlak dengan nilai sebenarnya. Penambahan nilai error pada Gambar 9, 10 dan 11 dilakukan untuk mengetahui jumlah persen error yang seluruh datanya dapat diterima.

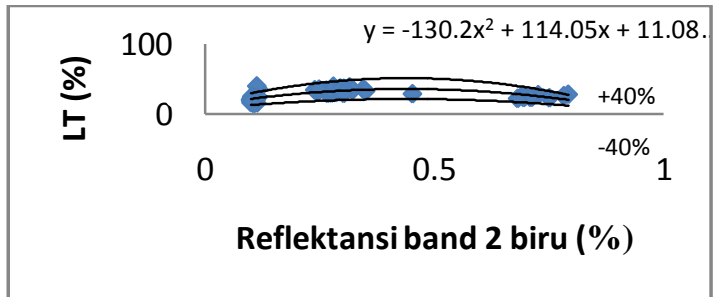

Gambar 8. Grafik hubungan antara reflektansi Band 2 citra Landsat 8 dengan lengas tanah (error $\pm 40 \%$ )

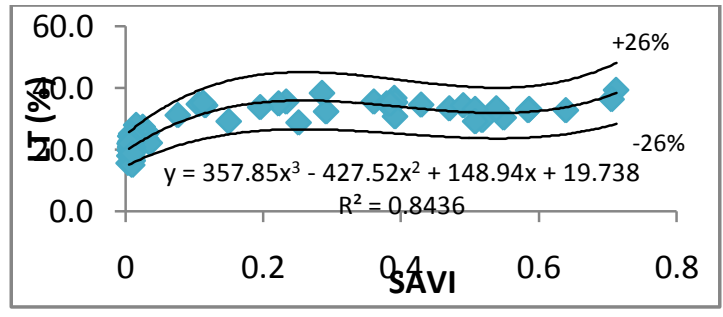

Gambar 9. Grafik hubungan antara SAVI citra Landsat 8 dengan lengas tanah (error $\pm 26 \%$ )

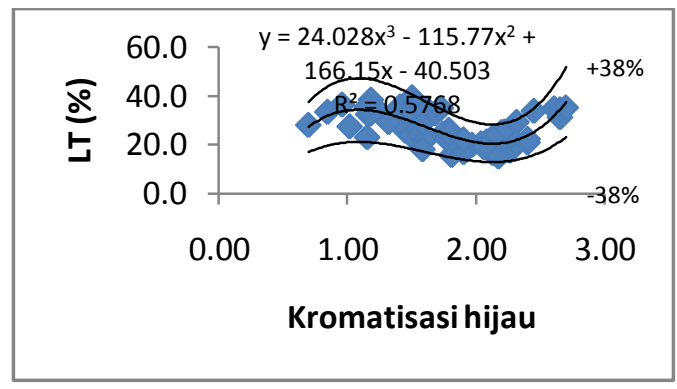

Gambar 10. Grafik hubungan antara kromatisasi hijau citra Landsat 8 dengan lengas tanah (error $\pm 38 \%$ )

\section{Peta Kontur Kadar Lengas Tanah}

Setelah mengetahui fungsi-fungsi apa saja yang dapat digunakan untuk memprediksi lengas tanah, maka dapat dibuatkan sebuah layout peta kontur lengas tanah guna mengetahui penyebaran lengas tanah di wilayah tersebut. Dari gambar dapat dilihat pula bahwa terdapat berbagai interval kontur kelengasan tanah yang terdapat di daerah tersebut. Pada Gambar 11 dapat dilihat bahwa daerah sekitar Bontorita terjadi pemusatan lengas tanah, jadi dapat disimpulkan bahwa di daerah tersebut memiliki lengas tanah yang sama. Sedangkan pada daerah Alluka, Manongkoki dan Biringbalang tidak terjadi pemusatan garis kontur. Hal tersebut dikarenakan jarak antar garis konturnya berjauhan. Pada gambar 12 daerah Bontorita dan Biringbalang terjadi pemusatan garis kontur yang berarti penyebaran kadar lengas tanah di daerah tersebut sama. Sedangkan pada Gambar 13 hanya daerah Manongkoki yang mengalami pemusatan garis kontur. Akan tetapi interval konturnya tetap beragam dibeberapa lokasi. 


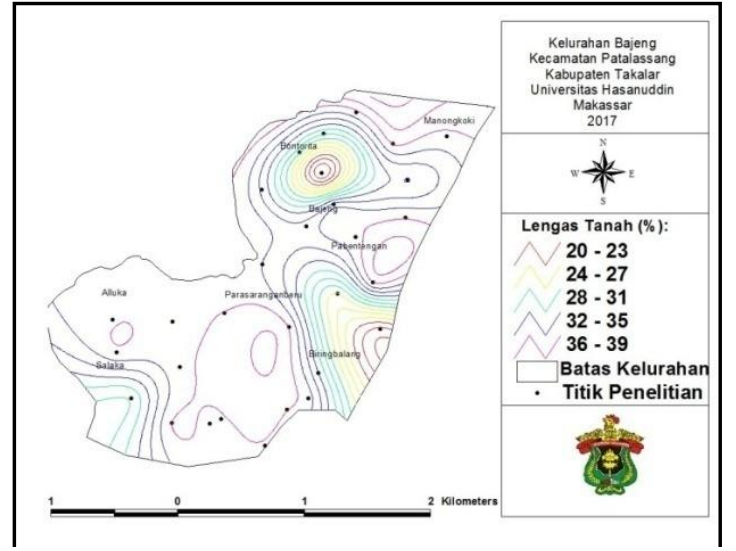

Gambar 11. Peta kontur lengas tanah fungsi band 2 biru

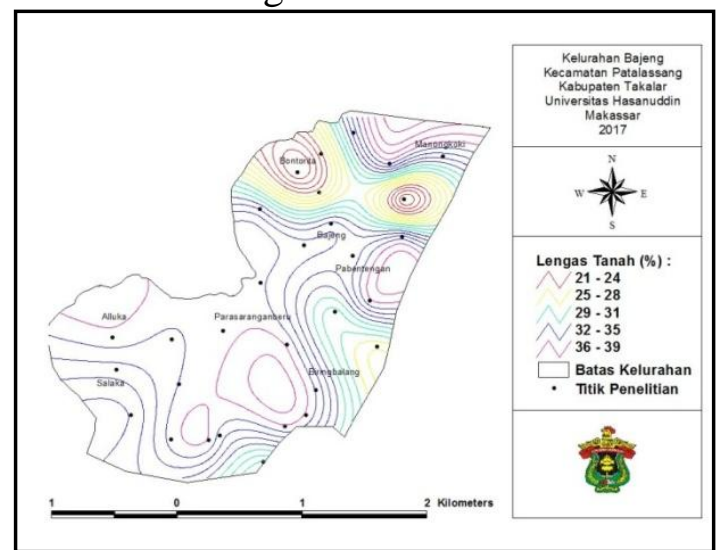

Gambar 12. Peta kontur lengas tanah fungsi SAVI

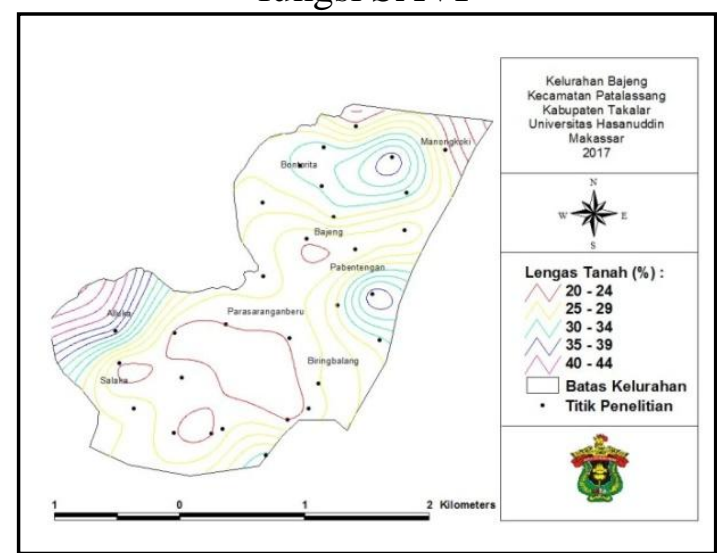

Gambar 13. Peta kontur lengas tanah fungsi kromatisasi hijau

\section{KESIMPULAN DAN SARAN}

\section{Kesimpulan}

Kesimpulan yang diperoleh dari penelitian ini adalah sebagai berikut:

1. Pendugaan kelengasan tanah dari komponen data citra Landsat 8 untuk band tunggal, yaitu pada band 2 biru menghasilkan koefisien determinasi $\left(\mathrm{R}^{2}\right)$ sebesar 0,653 dengan persamaan: $\mathrm{LT}=-130.2(\mathrm{~B} 2)^{2}+114.0(\mathrm{~B} 2)+11.08$

2. Pendugaan kelengasan tanah dari komponen data citra Landsat 8 untuk indeks vegetasi, yaitu Soil Adjusted Vegetation Index (SAVI) yang menghasilkan koefisien determinasi $\left(R^{2}\right)$ sebesar 0,843 dengan persamaan:

$$
\begin{aligned}
\mathrm{LT}= & 324.6\left((1+0,5) * \frac{\mathrm{B} 5-\mathrm{B} 4}{\mathrm{~B} 5+\mathrm{B} 4+0,5}\right)^{3}- \\
& 387.7((1+0,5) * \\
& \left.\frac{\mathrm{B} 5-\mathrm{B} 4}{\mathrm{~B} 5+\mathrm{B} 4+0,5}\right)^{2}+135.5((1+0,5) * \\
& \left.\frac{\mathrm{B} 5-\mathrm{B} 4}{\mathrm{~B} 5+\mathrm{B} 4+0,5}\right)+20.78
\end{aligned}
$$

3. pendugaan kelengasan tanah dari komponen data citra Landsat 8 untuk kromatisasi, yaitu kromatisasi hijau yang menghasilkan koefisien determinasi $\left(\mathrm{R}^{2}\right)$ sebesar 0,576 dengan persamaan:

$$
\begin{aligned}
\mathrm{LT}= & 2 \mathrm{E}+10\left(\frac{\mathrm{B} 3}{\mathrm{~B} 2+\mathrm{B} 3+\mathrm{B} 4}\right)^{3} \\
& 2 \mathrm{E}+10\left(\frac{\mathrm{B} 3}{\mathrm{~B} 2+\mathrm{B} 3+\mathrm{B} 4}\right)^{2} \\
& 8 \mathrm{E}+09\left(\frac{\mathrm{B} 3}{\mathrm{~B} 2+\mathrm{B} 3+\mathrm{B} 4}\right)-8 \mathrm{E}+08
\end{aligned}
$$

\section{Saran}

Untuk penelitian lanjutan, ada baiknya untuk menambah data atau variabel lainnya agar mendapatkan hasil yang lebih akurat.

\section{DAFTAR PUSTAKA}

Abdurachman, A.,Umi H, dan Ishak J. 2015. Penetapan Kadar Air Tanah Dengan Metode Gravimetrik. http://www.balittanah.litbang.perta nian.go.id.

Andana, E.K. 2015. Pengembangan Data Citra Satelit Landsat-8 Untuk Pemetaan Area Tanaman Hortikultura Dengan Berbagai Metode Algoritma Indeks Vegetasi. Institut Teknologi Sepuluh Nopembar: Surabaya. 
Anonim. 2011. Analisis Kelembaban Tanah Permukaan Melalui Citra Landsat 7 ETM+ Di Wilayah Dataran Kabupaten Purworejo. Universitas Muhammadiyah Surakarta: Surakarta.

Bahar, G. 2016. Prediksi Produksi Lahan Sawah Dengan Citra Fotografik Obliquemenggunakan Metode Mlp (Multi Layer Perceptron). Universitas Hasanuddin: Makassar.

Domiri, D.D. 2005. Pengembangan Model Pendugaan Kelengasan Lahan Menggunakan Data MODIS. Peneliti Bidang Pemantauan Sumber Daya Alam dan Lingkungan: LAPAN.

Fadli. 2012. Analisis Regresi. Universitas Sumatra Utara: Medan.

Irwan. 2014. Budidaya Tanama Hortikultura. Universitas Islam Negeri Maulana Malik Ibrahim: Malang.

Ismail. $2010 . \quad$ Kontur. http://aanpambudi.files.wordpress.c om.

Loppies, R. 2010. Karakteristik dan Spesifikasi Satelit Landsat. Inderaja: Bandung.

Mali, M.S dan Shukla J.P,. 2014. Estimation Of Soil Moisture By Remote Sensing and Field Methods: A Review. International Journal of Remote Sensing and Geoseience Vol 3.

Nurdin. 2012. Karakteristik Tanah Inceptisol. Universitas Sumatra Utara: Medan.

Petropoulos, P.G. 2013. Remote Sensing of Energy Fluxes and Soil Moisture Content. CRC Press Taylor \& Francis Group: London, New York.
Prahasta, E. 2008. Remote Sensing (Soft Cover): Praktis Penginderaan Jauh dan Pengolahan Citra Digital dengan Perangkat Lunak ER Mapper. Informatika Bandung: Bandung.

Puntodewo, A., Dewi, S dan Taringan, J. 2010. Penginderaan Jauh. http://www.cifor.org

Rahayu dan Danang S C. 2014. Koreksi Radiometrik Citra Landsat-8 KanalMultispektral Menggunakan Top Of Atmosphere (ToA)Untuk Mendukung Klasifikasi Penutup Lahan. Universitas Jendral Soedirman:Purwokerto, Jawa Tengah.

Ritawati, Sri, N, Dewi F, dan Fitriani. 2015. Changes in Soil Moisture Content and Yield of Several Peanut Varieties Arachis hypogaea L. were Given Drip Irrigation in Dry Land. Sultan Ageng Tirtayasa University: Banten.

Sinadia, B.S. 2015. Studi Kondisi Tanaman Kakao Di Kabupaten Mamuju Berdasarkan Sifat Spektral Menggunakan Citra Landsat 8 TM. Universitas Hasanuddin: Makassar.

Suwarto. 2013. Pengaruh Lengas Tanah Terhadap Serapan K dan Ketersediaannya Di Tanah Vertisol. Universitas Sumatra Utara: Medan.

Tanriverdi. C, KSU, Fakultesi. Z, Bolumu. T.Y.V.S, dan Kahramanmaras. 2006. A Review of Remote Sensing and Vegetation Indices in Precision Farming. Journal of Science and Engineering, 69-76. 